\title{
Sorption Kinetics, Isotherm and Thermodynamic Modeling of Defluoridation of Ground Water Using Natural Adsorbents
}

\author{
Aamna Balouch ${ }^{1,2^{*}}$, Mazhar Kolachi ${ }^{3}$, Farah Naz Talpur ${ }^{1}$, Humaira Khan ${ }^{4}$, Muhammad I. Bhanger ${ }^{1}$ \\ ${ }^{1}$ National Center of Excellence in Analytical Chemistry, University of Sindh, Jamshoro, Pakistan \\ ${ }^{2}$ Institute of Microengineering and Nanoelectronic, University Kebangsaan Malaysia, Bangi, Malaysia \\ ${ }^{3}$ Environmental Engineering \& Management, Mehran University of Engineering \& Technology, Jamshoro, Pakistan \\ ${ }^{4}$ Dr. M. A. Kazi Institute of Chemistry, University of Sindh, Jamshore, Pakistan \\ Email: *aamna_balouch@yahoo.com
}

Received March 5, 2013; revised April 15, 2013; accepted May 1, 2013

Copyright (C) 2013 Aamna Balouch et al. This is an open access article distributed under the Creative Commons Attribution License, which permits unrestricted use, distribution, and reproduction in any medium, provided the original work is properly cited.

\begin{abstract}
The aim of study is to investigate the removal ability of some natural adsorbents for fluoride ion from aqueous solution. The batch dynamic adsorption method was carried out at neutral $\mathrm{pH}$ as the functions of contact time, adsorbent dose, adsorbate concentration, temperature and effect of co-anions, which are commonly present in water. The sorption kinetics and equilibrium adsorption isotherms of fluoride on natural adsorbing materials had been investigated at aforementioned optimized. Equilibrium adsorption isotherms, viz., Freundlich and Langmuir isotherms were investigated. Lagergren and Morris-Weber kinetic equations were employed to find the rate constants. The negative enthalpy $\Delta H=$ $-46.54 \mathrm{KJ} \cdot \mathrm{mol}^{-1}$ and Gibbs free energy calculated was $\Delta G_{288-333}-(2.07785,3.08966,4.1064,4.90716$ and 5.38036 $\mathrm{KJ} \cdot \mathrm{mol}^{-1}$ ) respectively, envisage exothermic and spontaneous nature of sorption.
\end{abstract}

Keywords: Isotherm; Kinetics and Thermodynamic Modeling; Ground Water; Natural Adsorbent; Defluoridation

\section{Introduction}

Weathering and dissolution of minerals, emitted from volcanoes and marine aerosols are the natural sources of releasing fluorides into the environment [1-3]. Many anthropogenic activities such as combustion and process waters and waste from various industrial processes, including steel manufacture, primary aluminum, copper and nickel production, phosphate ore processing, phosphate fertilizer production and use, glass, brick and ceramic manufacturing and glue and adhesive production are also the reason of fluoride contamination [2,4-5].

Increased fluoride levels in drinking water have become a critical health issue in many countries due to prevailing skeletal and dental fluorosis [6-8]. Though fluoride is an essential constituent for both humans and animals, it can be detrimental to human health depending on its level in drinking water [9]. Beneficial level of fluoride to health is $<1.5 \mathrm{mg} / \mathrm{L}$ as recommended by WHO [10-12]. In Pakistan, the problem is common in Thar Desert, the ground water is highly contaminated and

\footnotetext{
*Corresponding author.
}

people are facing many diseases caused by high fluoride concentration $[8,13]$.

Several studies have been conducted to reduce the concentration of $\mathrm{F}^{-}$ion in drinking water for the benefits of common man. Adsorption is one of the significant techniques in which fluoride adsorbed onto a membrane, or a fixed bed packed with resin or other mineral particles. Many natural and low cost materials such as red mud [14-15], zirconium impregnated coconut shell carbon [16-17], cashew nut shell carbon [18], ground nut shell carbon [19] and clays [20-21] have been used as adsorbents for fluoride removal from drinking water. Recently, amorphous alumina supported on carbon nanotubes [22], natural zeolites [23] chemically activated carbon [24] aligned carbon nanotubes [25], ion exchange polymeric fiber [26], double hydrous oxide of $\mathrm{Al}$ and $\mathrm{Fe}$ $\left(\mathrm{Fe}_{2} \mathrm{O}_{3} \mathrm{Al}_{2} \mathrm{O}_{3} \cdot \mathrm{XH}_{2} \mathrm{O}\right)$ [27] bone charcoal [28] and activated alumina [29] have been assayed for removing fluoride from drinking water as well as industrial wastewater.

This paper concentrates on investigating low cost material for fluoride sorption which can effectively remove fluoride from aqueous solutions at a relatively low level. 
To overcome these problems and enhance the defluoradation capacity this study was carried out with the natural adsorbents (coal, brick powder, saw dust) to treat the contaminated water. These adsorbents are cheaper, abundant and easily available in huge amount.

This study leads to the assumption that fluoride deposition occurs by the forces of adsorption over the surface of the adsorbents; also the dynamics and kinetics of the adsorption process are discussed.

\section{Experimental}

\subsection{Apparatus and Materials}

781-pH/Ion meter ( $\Omega$ Metrohm, Herisau, Switzerland) with $\mathrm{Ag}, \mathrm{Ag} / \mathrm{Cl}$ reference electrode $6.0726 .100(\Omega \mathrm{Me}-$ trohm) and fluoride electrode 6.0502.150 ( $\Omega$ Metrohm) were used for the quantitative analysis of Fluoride and also for the $\mathrm{pH}$ measurement with $\mathrm{pH}$ electrode. Gallenkamp thermostated automatic shaker model BKS-305010, UK was used for the batch experiments at ambient temperature (ca. $25^{\circ} \mathrm{C}$ ).

Ion-Chromatography (I.C) ( $\Omega$ Metrohm, Switzerland) instrument 861 Advance Compact with 833 IC liquid handling unit equipped with self-regenerating suppressor consists of a double gradient peristaltic pump with a conductivity detector was used for validation and correlation of results obtained from 781-pH/Ion meter for the quantification of fluoride. The anion column $(4.0 \times 250$ $\mathrm{mm}^{2}$ ) METROSEP A SUPP 4 - 250 (6.1006.430) and Carbonate/bicarbonate buffer mobile phase was used in ion chromatographic study. Whatman no. 42, filter papers were used for all filtration procedures.

All analytical reagent grade chemicals are obtained from the indicated companies and used without any further purification. CDTA (cyclohexylenedinitrilotetraacetate) (Merck, Germany) Anhydrous Sodium fluoride, sodium hydroxide, sodium chloride and acetic acid (ethanoic acid) from (Aldrich Chemical Co.). The adsorbents (coal, brick powder and saw dust) were collected from local area of Hyderabad (Pakistan).

\subsection{Preparation of Stock Solutions Specifications}

Ultra pure water (conductivity $0.050 \mu \mathrm{S} \cdot \mathrm{cm}^{-1}$ ), obtained from a Milli-Q purification system (PURELAB Prima 7 BP, PURELAB Classic UV) was used for the preparation of all samples, standards and blanks. All glassware (pipettes, volumetric flasks, etc.) employed in the preparation of the stock solutions as well as working solutions were all initially cleaned by soaking in acidified (6 M nitric acid) water or in acidified $\left(\mathrm{HNO}_{3} 1.0 \mathrm{M}\right)$ solution of potassium permanganate, then thoroughly rinsed with deionized water and then acetone. The glassware was then dried for at least one hour in an oven at $120^{\circ} \mathrm{C}$.

The $1000 \mathrm{mg} / \mathrm{L}$ of fluoride stock solution was pre- pared by liquefying appropriate amount of anhydrous $\mathrm{NaF}$ in $100 \mathrm{ml}$ volumetric flask and then volume make up to the mark with Ultra pure water.

The adsorbents were first washed with distilled water followed by Milli Q Ultra pure water then dried oven at $105^{\circ} \mathrm{C}$ for $12 \mathrm{~h}$. After drying adsorbents were passed through sieve to obtain the required particle size for the present study.

No any impregnation or activation process was done before using the above adsorbents as well as these are easily available in rural area decreasing its cost as compare to previous reported materials.

A total ionic strength adjustment buffer (TISAB) buffer solution prepared for potentiometric measurement of fluoride by ion selective electrodes.

\subsection{Sorption Procedure}

The batch technique was used to examine the \%sorption of fluoride onto natural adsorbents at ambient temperature. Sorption of fluoride carried out by taking $10 \mathrm{~mL}$ of aqueous solution of fluoride $(5.0 \mathrm{mg} / \mathrm{L})$ was added to an Erlenmeyer flask containing $0.2 \mathrm{~g}$ of each dried and sieved adsorbent. The mixture was then shaken for a specified time $(10-100 \mathrm{~min})$ and temperature $\left(25^{\circ} \mathrm{C}\right)$ to allow adsorption of fluoride ion. The Erlenmeyer flasks were removed from shaker and allowed to stand for 2 min after attaining the required contact time. Then the mixture was filtered using then remainder was determined by TISAB method using fluoride ion selective electrode.

\subsection{Data Analysis}

The adsorption behavior of fluoride ion on the adsorbents e.g. coal, brick powder and saw dust surface was investigated using batch equilibrium experiments.

The sorbate concentration of sorbate on sorbent surface was calculated by the difference in the fluoride ion meter response $(\mathrm{mg} / \mathrm{L})$ before and after shaking. The distribution ratio $R_{d}$ and \%sorption of fluoride were calculated by using the following equations:

$$
\% \text { Sorption }=\frac{C_{i}-C_{\mathrm{e}}}{C_{i}} \times 100
$$

where $C_{i}$ and $C_{\mathrm{e}}$ is the initial and equilibrium concentrations $\left(\mathrm{mg} \cdot \mathrm{L}^{-1}\right)$ respectively.

All the experiments were performed in triplicate. The linear regression computer program with one independent variable was used for slope and statistical analyses of the data.

\section{Result and Discussion}

Sorption is a surface phenomenon and is affected significantly by physical and chemical characteristics of sorbent and sorbate. Sorption studies on natural adsorb- 
ent was carried out by optimizing various parameters, i.e. effect of agitation time, effect of shaking speed, amount of sorbent, $\mathrm{pH}$, concentration of sorbate and temperature.

\subsection{Effect of Agitation Time and Speed (rpm)}

Effect of shaking time on \%sorption of fluoride onto mixture of adsorbents was studied over an agitation time of $10-100 \mathrm{~min}$, using $0.2 \mathrm{~g}$ of each adsorbent temperature $25^{\circ} \mathrm{C}$ and $100 \mathrm{rpm}$ shaking speed. The results are shown in Figure 1. Percent adsorption increases from $60 \%$ to $90 \%$ at contact time is increased.

Sorption of fluoride as a function of shaking speed was also studied in the range of $25-150 \mathrm{rpm}$. It was found that \%sorption increases with increasing shaking speed and attains a maximum sorption at $100 \mathrm{rpm}$ and then \%sorption declines with increasing shaking speed as shown in Figure 2. Therefore for further studies $100 \mathrm{rpm}$ shaking speed was employed.

\subsection{Effect of Adsorbent Dose}

The effect of adsorbent dose on the removal of fluoride was studied by using different grams of adsorbent at 5.0

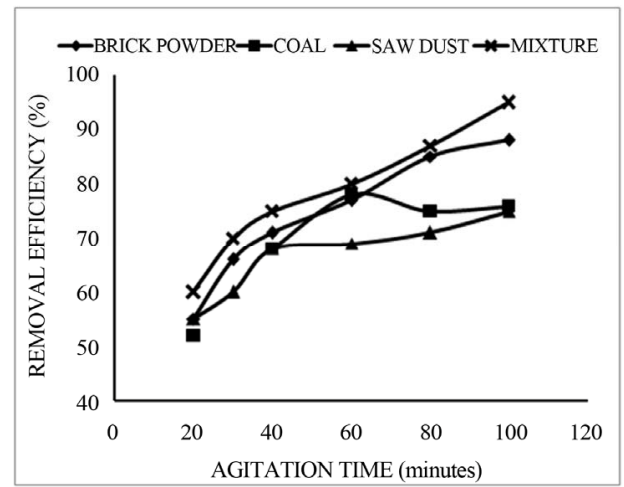

Figure 1. Percentage removal of Fluoride concentration as a contact time for the adsorbent (initial concentration $=\mathbf{5 . 0}$ $\mathrm{mg} / \mathrm{L}$, adsorbent dose $=1.0 \mathrm{~g}$ and $\mathrm{pH}$ 7.0).

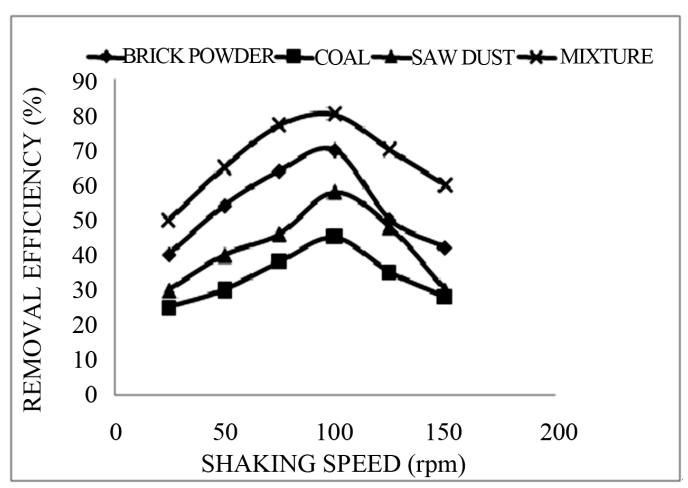

Figure 2. Percentage removal of Fluoride as a function of Shaking speed (initial concentration $=5.0 \mathrm{mg} / \mathrm{L}$, reaction time = $30 \mathrm{~min}$, and $\mathrm{pH}$ 7.0, Adsorbent dose $1.0 \mathrm{~g}$ ). $\mathrm{mg} / \mathrm{L}$ fixed fluoride concentration. As shown in Figure 3, the fluoride concentration is decreases as the adsorbent dose enhanced. It is manifest that the adsorption process is very fast and most of the fluoride adsorbed within first $10 \mathrm{~min}$ and the equilibrium reached within 40 mints. At the high absorbent doses (2.0 g) equilibrium requires shorter time $(20 \mathrm{~min})$ and lower absorbent doses $(0.1 \mathrm{~g})$ needs longer equilibrium time (40 $\mathrm{min})$. Therefore equilibration time of 30 mints was chosen to conduct further experiments at fixed adsorbent dose.

\subsection{Effect of $\mathbf{p H}$}

The influence of $\mathrm{pH}$ on the fluoride removal efficiency and capacity of the adsorbent were carried out for each adsorbent separately and also in mixture. Figure $\mathbf{4}$ shows adsorption capacity of untreated adsorbent at different fluoride concentration within the $\mathrm{pH}$ range of $4-9$ in mixture of all adsorbents. Sorption \% is achieved about $80 \%-90 \%$ at $\mathrm{pH} 5-7$ and due to better efficiency at $\mathrm{pH}$ 7 further study was carried out in neutral $\mathrm{pH}$.

\subsection{Isotherm Studies}

The sorption isotherms express the specific relation be-

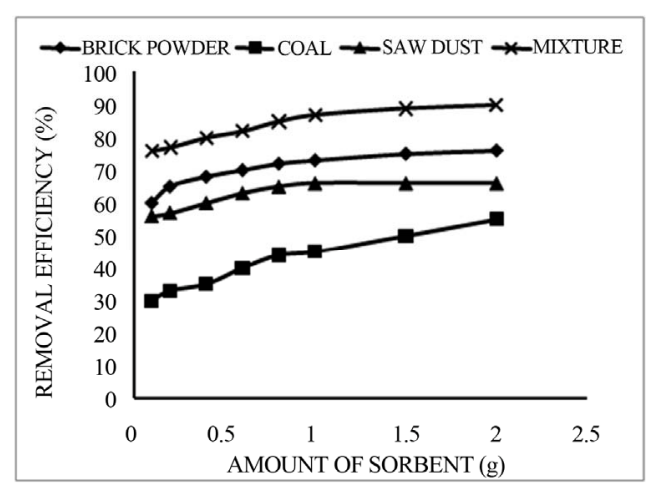

Figure 3. Percentage removal of Fluoride concentration as a function of adsorbent dose (initial concentration $=5.0 \mathrm{mg} / \mathrm{L}$, reaction time $=\mathbf{3 0} \mathrm{min}$, and $\mathrm{pH} \mathrm{7.0}$ ).

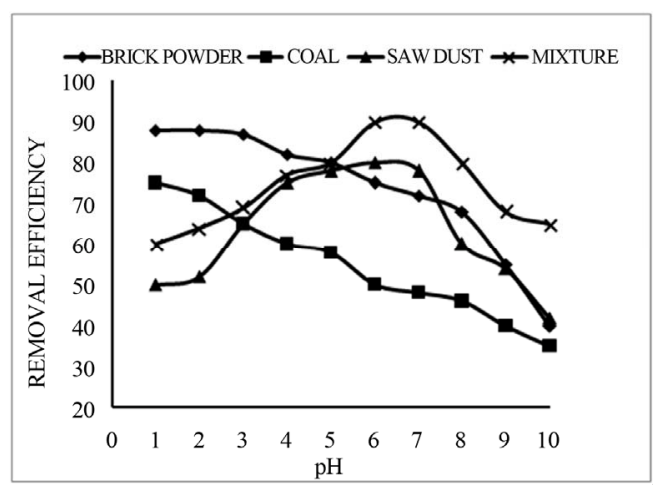

Figure 4. Percentage removal of Fluoride concentration as a function of $\mathrm{pH}$ for the adsorbent (initial concentration $=\mathbf{5 . 0}$ $\mathrm{mg} / \mathrm{L}$, reaction time $=30 \mathrm{~min}$, and adsorbent dose $=2 \mathrm{gm})$. 
tween the concentration of sorbate and its degree of accumulation onto sorbent surface at constant temperature. The Langmuir and Freundlich models are the simplest and most commonly used isotherms to represent the sorption of components from a liquid phase onto a solid phase [30].

The sorption capacities of coal, brick powder and saw dust for fluoride have been evaluated using different isotherms, namely Freundlich, Langmuir. Table 1 shows the comparison of Freundlich and Langmuir isotherm model.

\subsubsection{Freundlich Sorption Isotherm}

Freundlich isotherm gives the relationship between equilibrium liquid and solid phase capacity based on multilayer adsorption (heterogeneous surface). This isotherm is derived from the assumption that the adsorption sites are distributed exponentially with respect to heat of adsorption and given by [31] experimental data well on a phenomenological basis. The linearized form of Freundlich isotherm is tested in the following form:

$$
\log C_{\mathrm{ads}}=\log C_{m}+\frac{1}{n} \log C_{\mathrm{e}}
$$

where $1 / n$ is a characteristic constant related to sorption intensity, $C_{\mathrm{ads}}$ is the sorbed concentration of sorbate onto sorbent $\left(\mathrm{mol} \cdot \mathrm{g}^{-1}\right), C_{\mathrm{e}}$ represents equilibrium concentration of sorbate in solution, and $C_{m}$ is the multilayer sorption capacity of sorbent $\left(\mathrm{mol} \cdot \mathrm{g}^{-1}\right)$. Logarithmic plot of sorbed and equilibrium concentration gives a straight line with coefficient of determination close to unity $(0.95 \pm$ $0.032)$. The values of $1 / n(0.41 \pm 0.01)$ and $\mathrm{C}_{m}(0.31 \pm$ $\left.0.001 \mathrm{mmol} \cdot \mathrm{g}^{-1}\right)$ are derived from the slope and intercept of the straight line, respectively. Figure 5 shows Freundlich sorption isotherms of fluoride on adsorbents.

\subsubsection{Langmuir Isotherm}

Figure 6 shows the simplest theoretical model for monolayer sorption, i.e. Langmuir isotherm [32] of fluoride onto mixture of sorbents. The Langmuir model was originally developed to represent monolayer sorption on a set of distinct localized sorption sites. It gives uniform

Table 1. Isotherm (Freunlich and Langmuir) characteristic constants for fluoride ion sorption.

\begin{tabular}{ccc}
\hline \multicolumn{2}{c}{ Isotherm parameter } & Fluoride \\
\hline \multirow{2}{*}{$\begin{array}{c}\text { Freundlich } \\
\text { isotherm }\end{array}$} & $1 / n$ & $0.41 \pm 0.023$ \\
& $K\left(\mathrm{mmol} \cdot \mathrm{g}^{-1}\right)$ & $0.2488 \pm 0.25$ \\
& Correlation factor & $0.974 \pm 0.05$ \\
& $Q\left(\mathrm{mmol}^{-1} \mathrm{~g}^{-1}\right)$ & \\
& $b\left(\mathrm{~L} \cdot \mathrm{mol}^{-1}\right)$ & $0.6253 \pm 0.002$ \\
Langmuir isotherm & $\begin{array}{c}\text { Correlation factor } \\
\end{array}$ & $R_{L}($ dimensionless \\
& factor $)$ & $0.634 \pm 0.3) \times 10^{3}$ \\
& & $0.0278-0.9662$ \\
\hline
\end{tabular}

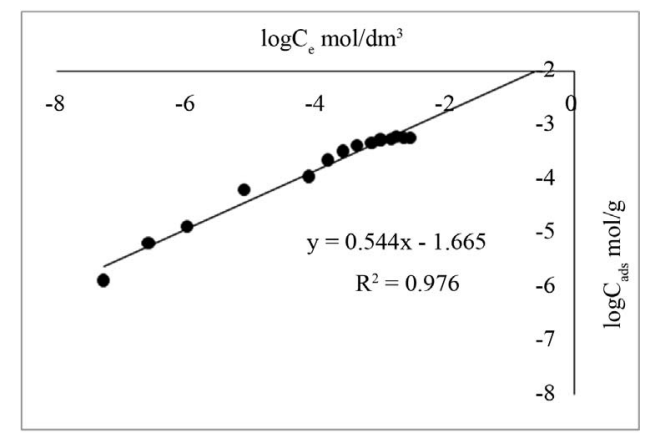

Figure 5. Freundlich sorption isotherms of Fluoride ion onto natural adsorbents.

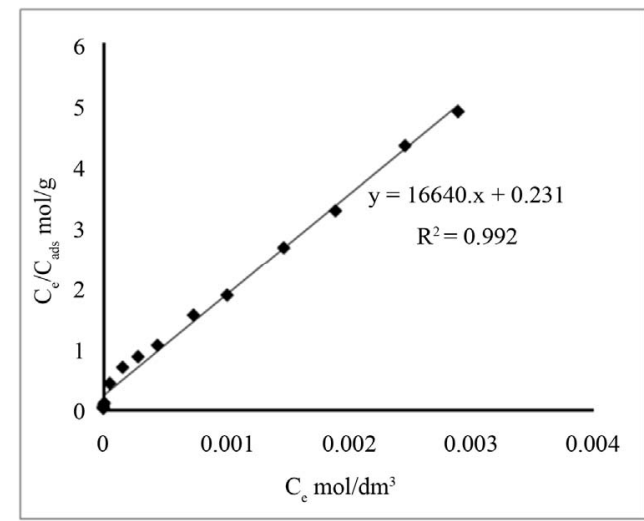

Figure 6. Langmuir sorption isotherms of Fluoride ion onto natural adsorbents.

energies of monolayer sorption onto sorbent surface with no transmigration of sorbate in the plane of the surface. There are no interactions between the sorbed molecules, no steric hindrance between sorbed molecules and incoming ions, and all the sorption sites are alike and uniform on microscopic scale. The sorption data is also applied to the following linearized form of Langmuir isotherm:

$$
\frac{C_{\mathrm{e}}}{C_{\mathrm{ads}}}=\frac{1}{Q_{b}}+\frac{C_{\mathrm{e}}}{Q}
$$

where $Q$ is the monolayer sorption saturation capacity $\left(\mathrm{mol} \cdot \mathrm{g}^{-1}\right)$, and $b$ represents the enthalpy of sorption $\left(\mathrm{dm}^{3} \cdot \mathrm{mol}^{-1}\right)$, independent of temperature. In Figure 6, $C_{\mathrm{e}} / C_{\text {ads }}$ is plotted against $C_{\mathrm{e}}$ yielding a straight line with $R^{2}(0.995 \pm 0.015)$ indicating that sorption data fit well into the Langmuir model. The value of $Q(0.0082 \pm$ $\left.0.00025 \mathrm{mmol} \cdot \mathrm{g}^{-1}\right)$ was calculated from the slope of the linear plot, whereas the value of $b(6.634 \pm 1.0) \times 10^{3}$ $\mathrm{dm}^{3} \cdot \mathrm{mol}^{-1}$ was derived from the intercept [33]. The essential characteristic of the Langmuir isotherm can be explained in terms of a dimensionless constant separation factor (RL), calculated using the equation:

$$
R_{L}=\frac{1}{1+b C_{i}}
$$


where $b$ is the Langmuir constant $\left(\mathrm{dm}^{3} \cdot \mathrm{mol}^{-1}\right)$ and $C_{i}$ is the initial concentration $\left(\mathrm{mol} \cdot \mathrm{dm}^{-3}\right)$. RL describes the type of the Langmuir isotherm [34]. The values of RL calculated were between $(0.02783-0.96625)$, indicating highly favorable sorption of fluoride on the adsorbent surface.

The RL values indicate the type of isotherm [35-36].

$\mathrm{RL}=0$ : irreversible isotherm;

$0<\mathrm{RL}<1$ : favorable isotherm;

$\mathrm{RL}=1$ : linear isotherm;

$\mathrm{RL}>1$ : unfavorable isotherm.

\subsection{Kinetics of Adsorption}

Kinetics of adsorption is one of the most attractive characteristics to be responsible for the efficiency of adsorption. To investigate the mechanism of adsorption Lagergren, Morris-Weber pseudo-first order and Ho and McKay pseudo-second order kinetic models have been applied for the experimental data to predict the adsorption kinetics [37-40]. The adsorption kinetics was studied with initial fluoride concentration of $5 \mathrm{mg} / \mathrm{L}$ and adsorbent dose $2.0 \mathrm{~g}$ at room temperature. The uptake of fluoride on adsorbents occurred rapidly, and reached equilibrium with in $40 \mathrm{~min}$. The Lagergren first-order kinetic model equation can be written as follows: Lagergren model

$$
\ln \left(q_{\mathrm{e}}-q_{t}\right)=\ln q_{\mathrm{e}}-\frac{k_{1} t}{2.303}
$$

The Lagergren model was tested by plotting $\ln \left(q_{\mathrm{e}}-q_{t}\right)$ versus $t$ (time), where $q_{\mathrm{e}}$ is the amount of fluoride sorbed $\left(\mathrm{mg} \cdot \mathrm{g}^{-1}\right)$ at equilibrium and $q_{t}$ at time $t(\mathrm{~min})$, and $k$ $\left(\mathrm{min}^{-1}\right)$ is the first-order rate constant. Figure 7 shows the kinetic study of fluoride on the adsorbents under optimized conditions. Plot of $\ln \left(q_{\mathrm{e}}-q_{t}\right)$ versus agitation time $t$ (mint) exhibit straight line with the coefficient of determination $\left(R^{2}\right)$ having values 0.9961 for fluoride.

The Equation (6) is applied for Morris-Weber model first-order kinetic mode.

$$
q_{t}=R_{d} \sqrt{t} \text { Morris-Weber model }
$$

$q_{t}$ is the sorbed concentration in $\mathrm{mol} \cdot \mathrm{g}^{-1}$ at time $t$, which was plotted against $\sqrt{t}$ to test the Morris-Weber equation.

In the intervening time, the same data were evaluated through the Morris-Weber model. Where $q_{t}$ was plotted against $\sqrt{t}$ that exhibits a straight line with the coefficient of determination $\left(R^{2}\right)$ having values of 0.8762 for fluoride, as shown in Figure 8.

The pseudo second-order rate model given by Ho and McKay in Equation (7) was also applied to investigate the data for kinetics of sorption.

$$
\frac{t}{q_{t}}=\frac{1}{k_{2} q_{\mathrm{e}}^{2}}+\frac{t}{q_{\mathrm{e}}} \text { Ho and Mckay model }
$$

Figure 9 shows a plot of $\left(\frac{t}{q_{t}}\right)$ versus $t$, which exhibits a straight line with $R^{2} 0.9998$ values for fluoride ion.

It is revealed after the kinetic model follow the Ho and McKay model, which elucidates the pseudo second-order kinetics of the sorption of fluoride ion on all adsorbents understudy.

\subsection{Thermodynamics Studies}

The effect of temperature on the sorption of fluoride onto

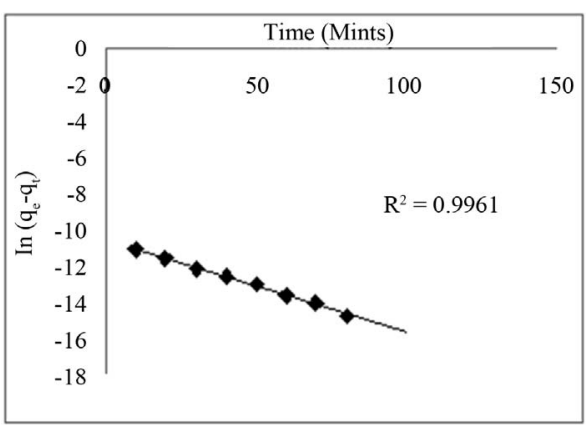

Figure 7. Lagergren model of Fluoride ion onto natural adsorbents.

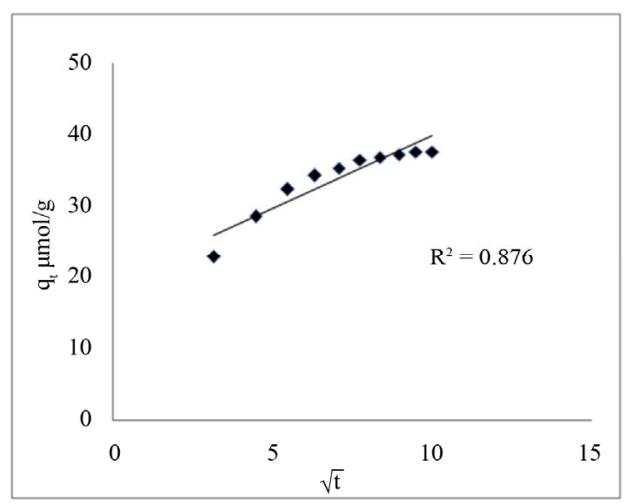

Figure 8. Morris-Weber model of Fluoride ion onto natural adsorbents.

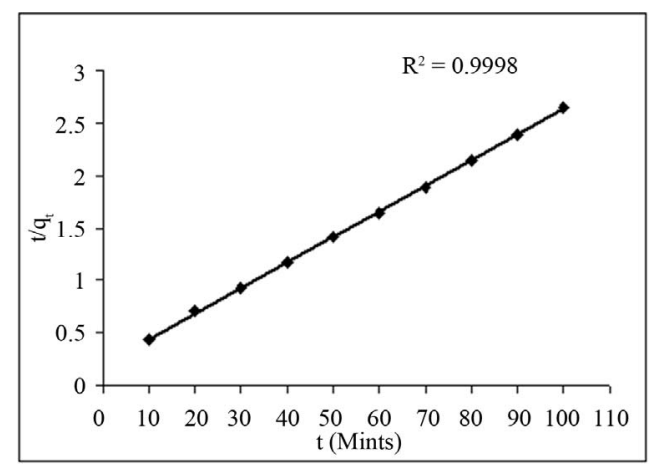

Figure 9. Ho and McKay model of fluoride onto natural adsorbents. 
natural adsorbents was studied in the range of $288-333$ $\mathrm{K}$ at optimum conditions. The plot of $\ln K_{c}$ verses $1 / \mathrm{K}$ gives a straight line with coefficient of determination $R^{2}$, 0.98 as shown in Figure 10.

The thermodynamic parameters, such as enthalpy $\Delta H$, entropy $\Delta S$, and Gibbs free energy $\Delta G$ were calculated using following equations:

$$
\begin{aligned}
\ln K_{c} & =-\frac{\Delta H}{R T}+\frac{\Delta S}{R} \\
\Delta G & =-R T \ln K_{c}
\end{aligned}
$$

where $\Delta H, \Delta S, \Delta G$, and $T$ are the enthalpy, entropy, Gibbs free energy, and absolute temperature, respectively. $R$ is the gas constant and $K_{C}$ the equilibrium constant. From the slope and intercept of plot, the values of $\Delta H$ $\left(-46.54 \pm 1 \mathrm{KJ} \cdot \mathrm{mol}^{-1}\right)$ and $\Delta S\left(0.1657 \mathrm{KJ} \cdot \mathrm{mol}^{-1} \cdot \mathrm{K}^{-1}\right)$ have been computed, while Gibbs free energy calculated was $\Delta G_{288-333 \mathrm{~K}-}(2.07785,3.08966,4.1064,4.90716$ and $5.38036 \mathrm{KJ} \cdot \mathrm{mol}^{-1}$ ) using Equation (9). The results are presented in Table 2.

It is revealed from the negative values of $\Delta H$ and $\Delta G$ that the sorption process is exothermic and spontaneous nature of sorption. The decrease in the value of $\Delta G$ with the increase of temperature shows that the reaction is more spontaneous at high temperature. The positive

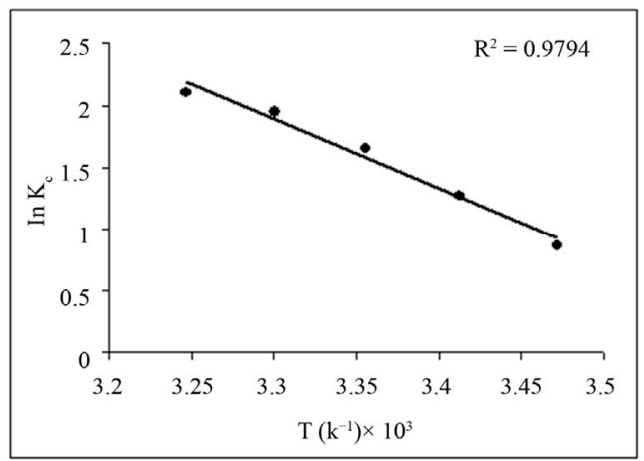

Figure 10. Effect of temperature on sorption of Fluoride ion.

Table 2. Thermodynamic parameters of fluoride sorption on Natural adsorbents.

\begin{tabular}{cccc}
\hline S. No & $\begin{array}{c}\text { Thermodynamic } \\
\text { parameters }\end{array}$ & Temperature & $\begin{array}{c}\text { Thermodynamic } \\
\text { values }\end{array}$ \\
\hline 1 & & 288 & -2.07785 \\
& & 293 & -3.08966 \\
& $\Delta G^{\circ} \mathrm{kJ} \cdot \mathrm{mol}^{-1}$ & 298 & -4.1064 \\
& & 303 & -4.90716 \\
& & 308 & -5.38036 \\
& $\Delta H^{\circ} \mathrm{kJ} \cdot \mathrm{mol}^{-1}$ & & -46.560304 \\
& $\Delta S^{\circ} \mathrm{kJ} \cdot \mathrm{mol}^{-1}$ & & 0.16572212 \\
\hline
\end{tabular}

value of entropy $\Delta S\left(0.1657 \mathrm{KJ} \cdot \mathrm{mol}^{-1} \cdot \mathrm{K}^{-1}\right)$ showed the increasing randomness at the solid/liquid interface and confirms the possibility of favorable adsorption.

\subsection{Determination of PZC of Adsorbents}

The typical definitions of points of zero charge is generally defined as the $\mathrm{pH}$ value where one or more components of the surface charge vanished and charge become zero at a specified temperature, pressure, and aqueous solution composition [41]. The concept of PZC is related to the phenomenon of adsorption. The PZC was determined by following the $\mathrm{pH}$ drift method recently reported in the literature [42-43].

The $\mathrm{pH}$ of the $\mathrm{NaCl}$ of ionic strength $0.01 \mathrm{M}$ was adjusted between 2 and 10 using $0.5 \mathrm{M} \mathrm{HCl}$ or $0.5 \mathrm{M}$ $\mathrm{NaOH}$. $0.5 \mathrm{~g}$ of adsorbent was added to $20 \mathrm{ml}$ of the $\mathrm{pH}$ adjusted solution in a capped tube and equilibrated for 24 $\mathrm{h}$ by constant shaking at ambient temperature. The final $\mathrm{pH}$ was measured and plotted against the initial $\mathrm{pH}$. The $\mathrm{pH}$ at which the curve crosses the initial $\mathrm{pH}=$ final $\mathrm{pH}$ line was taken as the PZC listed in Table $\mathbf{3}$ for each adsorbent.

\subsection{Application}

Under the optimized conditions the efficiency of natural adsorbents (coal, brick powder and saw dust) for the removal of fluoride ions from Groundwater samples collected from villages of Thar Desert Pakistan was tested to check the selectivity and applicability of the all adsorbents. A $100 \mathrm{ml}$ of ground water sample was taken to check directly (at optimum conditions). Another $100 \mathrm{ml}$ aliquot of sample was spiked with $2.0 \mathrm{mg}$ of fluoride ion and then treated with adsorbents as per procedure discussed. The fluoride ion were eluted with $0.2 \mathrm{~mol} \cdot \mathrm{L}^{-1}$ $\mathrm{HCl}$ and determined by ion selective electrode and results compared with the results obtained from ion chromatography. The results are given Table 4, which shows the suitability of natural adsorbents (coal, brick powder and saw dust) $t$ for preconcentration and removal of fluoride from environmental water samples. The physicochemical is reported in Table 5 .

\section{Conclusion}

The results showed those locally available cheap ad-

Table 3. Point of zero charge of adsorbents.

\begin{tabular}{ccc}
\hline S. No & Adsorbent & PZC \\
\hline 1 & Brick powder & 6.1 \\
2 & Coal & 7.2 \\
3 & saw dust & 4.9 \\
4 & Mixture of adsorbents & 6.9 \\
\hline
\end{tabular}


Table 4. Determination of Fluoride in environmental water samples.

\begin{tabular}{cccc}
\hline Samples & $\begin{array}{c}\text { Added } \\
\text { amount }\end{array}$ & Found & \%recovery \\
\hline S1 & 0.0 & 5.0 & 99.85 \\
& 2.0 & 6.99 & 100 \\
S2 & 0.0 & 3.06 & \\
& 2.0 & 5.06 & 100.33 \\
S3 & 0.0 & 0.92 & \\
& 2.0 & 3.0 & 99.17 \\
S4 & 0.0 & 1.65 & 100 \\
& 2.0 & 3.62 & \\
S5 & 0.0 & 4.33 & \\
& 2.0 & 6.33 & \\
\hline
\end{tabular}

Table 5. Physico-chemical parameter of water samples $(\mathrm{n}=$ 10).

\begin{tabular}{ccc}
\hline Parameters & $\begin{array}{c}\text { Result range of } \\
\text { observed parameter }\end{array}$ & RSD $^{\mathbf{a}}$ \\
\hline Fluoride & $0.01-5$ & 1.8 \\
TDS (mg/L) & $300-2500$ & 2.0 \\
Hardness (mg/L) & $20-500$ & 4.1 \\
Sulfate (mg/L) & $20-350$ & 3.8 \\
Chloride & $30-200$ & 2.6 \\
pH & $6.5-7.8$ & 0.4 \\
\hline
\end{tabular}

${ }^{\mathrm{a}}$ Relative standard deviation.

sorbents (coal, brick powder and saw dust) are potential adsorption material to remove fluoride from water hence involve no expenditure on transportation and have very low cost for pretreatment of fluoride. A mixture of all adsorbents was applied to remove fluoride from groundwater samples. The neutral $\mathrm{pH}$ was found to be highly favorable for utmost adsorption of fluoride; because of neutral $\mathrm{pH}$ it became very valuable and applicable for drinking water treatment, especially in poor areas. By making the column of these adsorbents, it will help the poor people to remove fluoride from the drinking water and make it safe.

\section{REFERENCES}

[1] M. K. Ahmad, S. Islam, S. Rahman, M. R. Haque and M. M. Islam, "Heavy Metals in Water, Sediment and Some Fishes of Buriganga River, Bangladesh," International Journal of Environmental Research, Vol. 4, No. 2, 2010, pp. 321-332.

[2] WHO, "Fluorides Environmental Health Criteria 227," World Health Organization, Geneva, 2002.

[3] C. M. Zvinowanda, J. O. Okonkwo, P. N. Shabalala and N. M. Agyei, "A Novel Adsorbent for Heavy Metal Remediation in Aqueous Environments," International Journal of Environmental Science Technology, Vol. 6, No. 3,
2009, pp. 425-434.

[4] J. Nouri, A. H. Mahvi, A. Babaei and E. Ahmadpour, "Regional Pattern Distribution of Groundwater Fluoride in the Shush Aquifer of Khuzestan County Iran," Research Report Fluoride, Vol. 39, No. 4, 2006, pp. 321325.

[5] P. Goyal, A. Sharma, S. Srivastava and M. M. Srivastava, "Saraca Indica Leaf Powder for Decontamination of $\mathrm{Pb}$ : Removal, Recovery, Adsorbent Characterization and Equilibrium Modeling," International Journal of Environmental Science, Technology, Vol. 5, No. 1, 2008, pp. 27-34.

[6] S. Ayoob and A. K. Gupta, "Fluoride in Drinking Water: A Review on the Status and Stress Effects," Critical Review Environmental Science and Technology, Vol. 36, No. 6, 2006, pp. 433-487. doi:10.1080/10643380600678112

[7] N. Mameri, A. R. Yeddou, H. Lounici, H. Grib, D. Belhocine and B. Bariou, "Defluoridation of Septentrional Sahara Water of North Africa by Electrocoagulation Process Using Bipolar Aluminium Electrodes," Water Research, Vol. 32, No. 5, 1998, pp. 1604-1610. doi:10.1016/S0043-1354(97)00357-6

[8] T. Rafique, S. Naseem, M. I. Bhanger and T. H. Usmani, "Fluoride Ion Contamination in the Groundwater of Mithi Sub-District, the Thar Desert, Pakistan," Environmental Geology, Vol. 56, No. 2, 2008, pp. 317-326. doi:10.1007/s00254-007-1167-y

[9] WHO, "International Standards for Drinking Water," 3rd Edition, WHO, Geneva, 2008.

[10] M. C. Bell and T. G. Ludwig, "The Supply of Fluoride to Man: Ingestion from Water," In: Fluorides and Human Health, WHO Monograph Series 59, World Health Organization, Geneva, 1970.

[11] WHO, "Guidelines for Drinking Water Quality," Vol. II: Health Criteria and Supporting Information, World Health Organization, Geneva, Switzerland, 1984.

[12] WHO, "Fluorides and Oral Health," World Health Organization Technical Report Series 846, World Health Organization, Geneva, 1994.

[13] T. Rafique, S. Naseem, T. H. Usmani, E. Bashir, F. A. Khan and M. I. Bhanger, "Geochemical Factors Controlling the Occurance of High Fluoride Ground Water in the Nagar Parkar Area, Sindh, Pakistan," Journal of Hazardous Material, Vol. 171, No. 1-3, 2009, pp. 424-430. doi:10.1016/j.jhazmat.2009.06.018

[14] Y. Cengeloglu, E. Kir and M. Ersoz, "Removal of Fluoride from Aqueous Solution by Using Red Mud," Separation and Purification Technology, Vol. 28, No. 1, 2002, pp. 81-86. doi:10.1016/S1383-5866(02)00016-3

[15] A. Tor, N. Danaoglu, G. Arslan and Y. Cengeloglu, "Removal of Fluoride from Water by Using Granular Red Mud: Batch and Column Studies," Journal of Hazardous Material, Vol. 164, No. 1, 2009, pp. 271-278. doi:10.1016/j.jhazmat.2008.08.011

[16] R. S. Sathish, N. S. R. Raju, G. S. Raju, G. N. Rao, K. A. Kumar and C. Janardhana, "Equilibrium and Kinetic Studies for Fluoride Adsorption from Water on Zirconium Impregnated Coconut Shell Carbon," Separation and Purification Technology, Vol. 42, No. 4, 2007, pp. 769-788. 
[17] A. J. Arulanantham, T. R. Krishna and N. Balasubramaniam, "Studies on Fluoride Removal by Coconut Shell Carbon," Indian Journal of Environmental Health, Vol. 13, No. 5, 1992, pp. 531-536.

[18] R. L. Ramos, J. R. Utrilla, N. A. Medellin-Castillo and M. S. Polo, "Kinetic Modeling of Fluoride Adsorption from Aqueous Solution onto Bone Char," Chemical Engineering Journal, Vol. 158, No. 3, 2010, pp. 458-467. doi:10.1016/j.cej.2010.01.019

[19] G. Alagumuthu and M. Rajan, "Kinetic and Equilibrium Studies on Fluoride Removal by Zirconium (IV): Impregnated Groundnut Shell Carbon," Hemijska Industrija, Vol. 64, No. 1, 2010, pp. 295-304.

[20] A. Tor, "Removal of Fluoride from an Aqueous Solution by Using Montmorillonite," Desalination, Vol. 201, No. 1-3, 2006, pp. 267-276. doi:10.1016/j.desal.2006.06.003

[21] G. Karthikeyan, M. N. Andal and S. G. Sundar, "Defluoridation Property of Burnt Clay," Journal of Indian Water Works Association, Vol. 31, No. 4, 1999, pp. 291300.

[22] Y. H. Li, S. Wang, A. Cao, D. Zhao, X. Zhang, J. Wei, C. $\mathrm{Xu}, \mathrm{Z}$. Luan, D. Ruan, J. Liang, D. Wu and B. Wei, “Adsorption of Fluoride from Water by Amorphous Alumina Supported on Carbon Nanotubes," Chemical Physics Letters, Vol. 350, No. 5, 2001, pp. 412-416. doi:10.1016/S0009-2614(01)01351-3

[23] P. K. Shrivastava and A. Deshmukh, "Defluoridation of Water with Natural Zeolite," Journal of the Institution of Public Health Engineers (India), Vol. 14, No. 2, 1994, pp. 11-14.

[24] K. Muthukumaran, N. Balasubramaniam and T. V. Ramkrishna, "Removal of Fluoride by Chemically Activated Carbon," Indian Journal of Environmental Protection, Vol. 12, No. 1, 1995, pp. 514-517.

[25] Y. H. Li, S. Wang, X. Zhang, J. Wei, C. Xu, Z. Luan and $\mathrm{D}$. Wu, "Adsorption of Fluoride from Water by Aligned Carbon Nanotubes," Materials Research Bulletin, Vol. 38, No. 3, 2003, pp. 469-476. doi:10.1016/S0025-5408(02)01063-2

[26] R. X. Liu, J. L. Guo and H. X. Tang, "Adsorption of Fluoride, Phosphate, and Arsenate Ions on a New Type of Ion Exchange Fiber," Journal of Colloid and Interface Science, Vol. 248, No. 2, 2002, pp. 268-274. doi:10.1006/jcis.2002.8260

[27] N. I. Chubar, V. F. Samanidou, V. S. Kouts, G. G. Gallios, V. A. Kanibolotsky, V. V. Strelko and I. Z. Zhuravlev, "Adsorption of Fluoride, Chloride, Bromide, and Bromate Ions on a Novel Ion Exchanger," Journal of Colloid and Interface Science, Vol. 291, No. 1, 2005, pp. 67-74. doi:10.1016/j.jcis.2005.04.086

[28] D. J. Killedar and D. S. Bhargava, "Effect of Stirring Rate and Temperature on Fluoride Removal by Fishbone Charcoal," Indian Journal of Environmental Health, Vol. 35, No. 2, 1993, pp. 81-87.

[29] S. Kumar, "Studies on Desorption of Fluoride from Activated Alumina," Indian Journal of Environmental Health, Vol. 16, No. 1, 1995, pp. 50-53.
[30] V. M. Boddu, K. Abburi, I. L. Talbolt and E. D. Smith, "Removal of Hexavalent Chromium from Wastewater Using a New Composite Chitosan Biosorbent," Environmental Science \& Technology, Vol. 39, No. 19, 2003, pp. 4449-4456. doi:10.1021/es021013a

[31] H. Freundlich, "Uber Die Adsorption in Losungen," Zeitschrift für Physikalische Chemie, Vol. 57, 1985, pp. 385-470.

[32] I. Langmuir, "The Adsorption of Gases on Plane Surface of Gases on Plane Surface of Glass, Mica and Platinum," Journal of the Chemical Society, Vol. 40, No. 9, 1918, pp. 1361-1403. doi:10.1021/ja02242a004

[33] M. M. Dubinin and L. V. Radushkevich, "Equation of the Characteristic Curve of Activated Charcoal," Proceedings of the Academy of Sciences of the USSR: Physical Chemistry Section, Vol. 55, No. 1, 1947, pp. 331-337.

[34] D. B. Singh, D. O. Rupainwar, G. Prasad and K. C. Jayaprakas, "Study on the Cd Removal from Water by Adsorption," Journal of Hazardous Materials, Vol. 60, No. 1, 1998, pp. 29-40. doi:10.1016/S0304-3894(97)00071-X

[35] J. R. Memon, S. Q. Memon, M. I. Bhanger, G. Z. Memon, A. El Turki and G. C. Allend, "Characterization of Banana Peel by Scanning Electron Microscopy and FT-IR Spectroscopy and Its Use for Cadmium Removal," Colloids and Surfaces B: Biointerfaces, Vol. 66, No. 2, 2008, pp. 260-265. doi:10.1016/j.colsurfb.2008.07.001

[36] I. B. Solangi, S. Memon and M. I. Bhanger, "Removal of Fluoride from Aqueous Environment by Modified Amberlite Resin," Journal of Hazardous Materials, Vol. 171, No. 1-3, 2009, pp. 815-819. doi:10.1016/j.jhazmat.2009.06.072

[37] S. Lagergren, "Zur Theorie der Sogenannten Adsorption Gelöster Stoffe, Kungliga Svenska Vetenskapsakademiens," Handlingar, Vol. 24, No. 4, 1898, pp. 1-39.

[38] E. Haribabu, Y. D. Upadhya and S. N. Upadhyay, "Removal of Phenols from Effluents by Fly Ash," Journal of Environmental Studies, Vol. 43, No. 2, 1993, pp. 169-176. doi:10.1080/00207239308710824

[39] W. J. Weber and J. C. Morris, "Kinetics of Adsorption of Carbon from Solution," Journal of the Sanitary Engineering Division, American Society of Civil Engineering, Vol. 89, No. 1, 1963, pp. 31-60.

[40] Y. S. Ho and G. McKay, "Pseudo-Secondorder Model for Sorption Processes," Process Biochemistry, Vol. 34, No. 4, 1999, pp. 451-456. doi:10.1016/S0032-9592(98)00112-5

[41] G. Sposito, "The Surface Chemistry of Soils," Oxford University Press, New York, 1984, p. 81.

[42] M. N. Khan and A. Sarwar, "Determination of Points of Zero Charge of Natural and Treated Adsorbents," Surface Review and Letters, Vol. 14, No. 3, 2007, pp. 461-469. doi:10.1142/S0218625X07009517

[43] Y. Yang, Y. Chun, G. Sheng and M. Huang, "pH-Dependence of Pesticide Adsorption by Wheat-Residue-Derived Black Carbon," Langmuir, Vol. 20, No. 16, 2004, pp. 6736-6741. doi:10.1021/la049363t 